\title{
Early childhood health, growth, and neurodevelopmental outcomes after complete repair of total anomalous pulmonary venous connection at $\mathbf{6}$ weeks or younger
}

Gwen Y. Alton, RN, BSN, ${ }^{\mathrm{a}, \mathrm{c}}$ Charlene M. T. Robertson, MD, FRCP(C) ${ }^{\mathrm{a}, \mathrm{c}}$ Reg Sauve, MD, FRCP(C), ${ }^{d}$ Abhay Divekar, MD, FRCP(C), ${ }^{f}$ Alberto Nettel-Aguirre, $\mathrm{PhD},{ }^{\mathrm{d}, \mathrm{e}}$ Sharon Selzer, RN, ${ }^{g}$ Ari R. Joffe, MD, FRCP(C), ${ }^{a}$ Ivan M. Rebeyka, MD, FRCS(C), ${ }^{\mathrm{a}, \mathrm{b}}$ David B. Ross, MD, FRCS(C), ${ }^{\mathrm{b}}$ and the Western Canadian Complex Pediatric Therapies Project Follow-Up Group*

Supplemental material is available online.
From the Departments of Pediatrics ${ }^{\mathrm{a}}$ and Surgery, ${ }^{\mathrm{b}}$ University of Alberta, Edmonton, Alberta, Canada, Neonatal and Infant Follow-up Clinic, Glenrose Rehabilitation Hospital, Edmonton, Alberta, Canada, ${ }^{\mathrm{c}}$ the Department of Pediatrics, ${ }^{\mathrm{d}}$ and Research Methods Team, Faculty of Medicine, ${ }^{e}$ University of Calgary, Calgary, Alberta, Canada, the Division of Pediatric Cardiology, University of Manitoba, Winnipeg, Manitoba, Canada, ${ }^{\mathrm{f}}$ and the Department of Pediatrics, General Hospital, Regina, Saskatchewan, Canada. $^{\mathrm{g}}$

Supported initially by the Glenrose Rehabilitation Hospital Research Trust Fund, with ongoing operational funding from The Registry and Follow-up of Complex Pediatric Therapies Project, Alberta Health and Wellness.

Received for publication Sept 27, 2006; revisions received Nov 22, 2006; accepted for publication Dec 13, 2006.

Address for reprints: Charlene M. T. Robertson, MD, FRCP(C), Room 242A Glen East, Glenrose Rehabilitation Hospital, 10230111 Ave, Edmonton, Alberta, Canada T5G 0B7 (E-mail: croberts@cha.ab.ca).

*D. Moddemann, Winnipeg, Manitoba, P. Blakley, Saskatoon, Saskatchewan, and A. Ninan, Regina, Saskatchewan.

J Thorac Cardiovasc Surg 2007;133:905-11 $0022-5223 / \$ 32.00$

Copyright $(92007$ by The American Association for Thoracic Surgery

doi:10.1016/j.jtcvs.2006.12.012
Objective: This interprovincial inception cohort study explores early childhood outcomes and their operative and perioperative predictors after total anomalous pulmonary venous connection repair, simple (patent ductus arteriosus, atrial septal defect, or both) or complex (any associated major cardiac anomalies).

Methods: From 1996 through 2004, a total of 41 consecutive neonates with total anomalous pulmonary venous connection underwent complete repair with deep hypothermic circulatory arrest. Multidisciplinary health and neurodevelopmental outcomes (Bayley Scales of Infant Development II [1993], Mental and Psychomotor Developmental Indices) were assessed at 18 to 24 months of age. Regression analyses explored potentially modifiable predictors of outcome.

Results: Survival after simple total anomalous pulmonary venous connection repair was 31 of 32 (97\%); that after complex repair was 3 of 9 (33\%). Relative risk of death was higher for complex (21.3) and obstructive (8.4) total anomalous pulmonary venous connections. Those who died had longer deep hypothermic circulatory arrest times $(P<.001)$. For 34 survivors, Mental Developmental Index was $87 \pm$ 16 and Psychomotor Developmental Index was $89 \pm 13$. Among survivors, $24.6 \%$ of variability in Mental Developmental Index was explained by its linear relationship with socioeconomic status, whereas $35.5 \%$ of variability in Psychomotor Developmental Index was explained by its linear relationship with weight at surgery and highest plasma lactate level after surgery. North American native peoples made up $38 \%$ of survivors, a higher than expected number.

Conclusion: Mean developmental scores were in the low average range of normative data. Socioeconomic factors predicted mental outcome. High postoperative lactate level on day 1 predicted low motor scores. Other potentially modifiable variables will need to be explored. Further epidemiologic study relating race to occurrence of total anomalous pulmonary venous connection is suggested. Early neurodevelopmental assessment is recommended.

$\mathrm{T}$ otal anomalous pulmonary venous connection (TAPVC) accounts for approximately $2 \%$ of congenital heart disease.$^{1-4}$ Reported mortality for simple TAPVC is $4.9 \%$ to $6.8 \%,{ }^{5,6}$ whereas that for complex TAPVC with other associated cardiac anomalies is greater than $50 \%{ }^{7}$ Survivors after simple TAPVC repair have good long-term school attendance and employment. ${ }^{8}$ Parental reports suggest good general health, with $69 \%$ of survivors having average or above school performance. ${ }^{9}$ School-aged assessments report full-scale and verbal intelligence to be similar to population norms, but survivors have reduced performance scores, 


\section{Abbreviations and Acronyms \\ MDI = Bayley Scales of Infant Development II Mental Developmental Index \\ PDI = Bayley Scales of Infant Development II Psychomotor Developmental Index \\ $\mathrm{TAPVC}=$ total anomalous pulmonary venous connection}

visual-motor integration, and fine motor skills. ${ }^{10}$ Little has been published about early childhood neurodevelopmental outcomes after TAPVC repair.

There is increasing awareness of the importance of assessing neurodevelopmental outcomes after neonatal cardiac surgery for complex congenital heart disease, and mechanisms for adverse outcomes have been proposed. ${ }^{11}$ Assessments after neonatal cardiac surgery allow standardized results of neurodevelopmental outcomes and identification of those needing early childhood educational interventions. ${ }^{12}$

The objectives of this study were to describe the 18 - to 24-month health, growth, and neurodevelopmental outcomes for all infants 6 weeks or younger undergoing intracardiac repair for simple (patent ductus arteriosus, atrial septal defect, or both) or complex (other associated major cardiac anomalies) TAPVC and to explore the proportions of variability in outcomes explained by demographic, operative, and perioperative variables.

\section{Materials and Methods}

This interprovincial inception cohort outcomes study was conducted in three provinces in Western Canada. As previously described, ${ }^{13,14}$ from September 1996 through August 2004, infants 6 weeks or younger were identified at time of surgery for TAPVC (simple and complex). Surgery was performed at the Stollery Children's Hospital, Edmonton, Alberta, Canada. Although reporting outcomes for those with simple TAPVC only would provide a cleaner study, there is need for information about those with complex abnormalities. Data for both simple and complex TAPVC are therefore given.

The operative management for the repair of TAPVC at our institution during this time was to cool the patient's blood to $20^{\circ} \mathrm{C}$ or lower for a minimum of 20 minutes before deep hypothermic circulatory arrest. We report here both the lowest blood temperature immediately before deep hypothermic circulatory arrest (in ${ }^{\circ} \mathrm{C}$ ) and the lowest rectal temperature on cardiopulmonary bypass for longer than 10 minutes (also in ${ }^{\circ} \mathrm{C}$ ). A modified $\mathrm{pH}$-stat cooling strategy was used. The hematocrit during cooling for this cohort was greater than $0.20 \mathrm{~L}$, whereas current levels are greater than $0.25 \mathrm{~L}$. Preoperative, intraoperative, and postoperative variables that had been agreed on previously were collected prospectively and have been described elsewhere. ${ }^{13,14}$ Of particular interest was plasma lactate level as an indicator of outcome; levels were regularly measured twice daily as part of clinical management as well as obtained routinely with blood gas values. Long-term follow-up was discussed with parents or guardians once survival was probable. With appropriate consent, contact was made with the respective follow-up clinic at the tertiary site of origin.

\section{Subjects}

All 41 consecutive patients admitted with TAPVC from September 1996 through August 2004-28 (68\%) boys, 28 (68\%) referred from out of region, and 14 (34\%) North American native peoples-were registered. There were no exclusions to enrollment. All 34 survivors ( 31 with simple TAPVC and 3 with complex) received multidisciplinary neurodevelopmental assessments through existing neonatal follow-up clinics: 25 (74\%) in Calgary, Alberta, Regina and Saskatoon, Saskatchewan, or Winnipeg, Manitoba, and $9(26 \%)$ at the Neonatal and Infant Follow-up Clinic at the Glenrose Rehabilitation Hospital, Edmonton, Alberta. Ethics board approvals were obtained from each site before onset of the study. All parents or guardians signed individual consent forms.

\section{Early Childhood Assessments}

Outcomes assessment was completed at 18 to 24 months (mean 21 months). At assessment, a research nurse recorded history of hospitalizations, illnesses, medication use, and need for supplemental oxygen. Physical measurements were obtained as described previously. ${ }^{13,14}$ The family socioeconomic status was determined according to the Blishen Index, a formula that considers the relative income, education requirement, and prestige factor of employment with a population mean $\left( \pm\right.$ SD) of $43 \pm 13 .{ }^{15}$ Maternal education was indicated by years of schooling. Race was coded according to National Institutes of Health specifications. ${ }^{16}$ Pediatricians experienced in neurodevelopmental follow-up examined each child for evidence of cerebral palsy ${ }^{17}$ or visual impairment, defined as corrected visual acuity in the better eye worse than $20 / 60 .{ }^{13,14}$ Hearing was evaluated by experienced certified pediatric audiologists in soundproof environments as described elsewhere. ${ }^{13,14}$ Hearing impairment was defined as binaural or bilateral sensorineural hearing loss greater than $40 \mathrm{~dB}$ at any frequency from 250 to $4000 \mathrm{~Hz}{ }^{13,14}$ Certified pediatric psychologists and psychometrists administered The Bayley Scales of Infant Development II, ${ }^{18}$ a widely accepted standardized outcome measure used in neonatal follow-up clinics that yields separate Mental Developmental Index (MDI) and Psychomotor Developmental Index (PDI) scores, each with a mean of 100 and SD of 15. Developmental indices lower than 70 (2 SD below mean) indicated mental or motor delay.

\section{Statistical Analysis}

Descriptive variables for outcomes were analyzed with the univariate $t$ test, $\chi^{2}$ test, and Fisher exact test (2-sided) analyses. Bonferroni correction was applied. The relative risk for death was calculated. Sequential stepwise multiple regressions for variables from each of the five stages-preoperative, operative, postoperative day 1, postoperative days 2 to 5 , and postoperative days 6 and after-were used to explore the overall greatest proportion of outcome explained by a combination of predictors to a significance level of .05. Because numbers of survivors with complex TAPVC were small, analysis of variables predictive of outcome for this 
TABLE 1. Descriptive anatomic and operative characteristics of 41 infants 6 weeks or younger undergoing complete repair for total anomalous pulmonary venous connection

\begin{tabular}{|c|c|c|c|c|c|}
\hline Descriptor & $\begin{array}{l}\text { Total } \\
\text { (n }=41)\end{array}$ & $\begin{array}{l}\text { Survivors } \\
\text { ( } \mathrm{n}=34)\end{array}$ & $\begin{array}{l}\text { Deaths } \\
(\mathrm{n}=7)\end{array}$ & $\begin{array}{l}\chi^{2} \text { or } 2 \text {-sided } \\
t \text { test }\end{array}$ & $P$ value \\
\hline Complex total anomalous pulmonary venous connection (No.) & $9(21.9 \%)$ & $3(8.8 \%)$ & $6(85.7 \%)$ & 20.032 & $<.001$ \\
\hline Male sex (No.) & $28(68 \%)$ & $21(61.8 \%)$ & $7(100 \%)$ & 3.919 & .048 \\
\hline Anatomy (No.) & & & & 10.598 & .014 \\
\hline Supracardiac & $17(41.5 \%)$ & $15(44.1 \%)$ & $2(28.6 \%)$ & & \\
\hline Infracardiac & $19(46.3 \%)$ & $17(50.0 \%)$ & $2(28.6 \%)$ & & \\
\hline Cardiac & $1(2.4 \%)$ & $1(2.9 \%)$ & $0(0 \%)$ & & \\
\hline Mixed & $4(9.8 \%)$ & $1(2.9 \%)$ & $3(42.9 \%)$ & & \\
\hline Obstructive & $17(41.5 \%)$ & $11(32.4 \%)$ & $6(85.7 \%)$ & 6.810 & .009 \\
\hline CPB time (min, mean $\pm S D$ ) & $70 \pm 30$ & $64 \pm 22$ & $100 \pm 48$ & -1.967 & .083 \\
\hline $\begin{array}{l}\text { Lowest mean arterial pressure on CPB for }>10 \mathrm{~min}(\mathrm{~mm} \mathrm{Hg} \text {, } \\
\text { mean } \pm \mathrm{SD})\end{array}$ & $24 \pm 7$ & $24 \pm 7$ & $25 \pm 7$ & -0.439 & .663 \\
\hline Lowest flow on CPB for $>10 \min (\mathrm{mL} /[\mathrm{kg} \cdot \min ]$, mean $\pm \mathrm{SD})$ & $129 \pm 23$ & $129 \pm 24$ & $128 \pm 23$ & 0.166 & .869 \\
\hline Lowest rectal temperature for $>10$ min on $\mathrm{CPB}\left({ }^{\circ} \mathrm{C}\right.$, mean $\left.\pm \mathrm{SD}\right)$ & $24.3 \pm 3.1$ & $24.2 \pm 3.2$ & $24.9 \pm 2.4$ & -0.571 & .571 \\
\hline $\begin{array}{l}\text { Lowest blood temperature immediately before } \mathrm{DHCA}\left({ }^{\circ} \mathrm{C} \text {, mean }\right. \\
\pm \mathrm{SD})\end{array}$ & $19 \pm 2.4$ & $19 \pm 3.3$ & $20 \pm 2.8$ & -1.444 & .157 \\
\hline Crossclamp time (min, mean $\pm S D)$ & $37 \pm 18$ & $36 \pm 16$ & $48 \pm 19$ & -2.004 & .052 \\
\hline DHCA time (min, mean \pm SD) & $29 \pm 11$ & $27 \pm 9$ & $41 \pm 14$ & -3.408 & .002 \\
\hline
\end{tabular}

After Bonferroni correction, only differences of $<.005$ remain significant. CPB, Cardiopulmonary bypass; DHCA, deep hypothermic circulatory arrest.

group could not be completed separately. SPSS version 12.0 for Windows (SPSS, Inc, Chicago, Ill) was used for analyses.

\section{Results}

Of the 41 children, 32 had simple TAPVC (14 supracardiac, 15 infracardiac, 1 cardiac, and 2 mixed; 11 obstructive and 21 not obstructed) and 9 had complex TAPVC (3 supracardiac, 4 infracardiac, and 2 mixed; 6 obstructive and 3 not obstructed). Table E1 gives the anatomic diagnoses of the 9 infants with complex TAPVC.

The anatomic and operative variables for all 41 infants undergoing repair (32 simple, 9 complex) at 6 weeks or younger are given in Table 1 . The relative risks for death among the 41 children were as follows: complex TAPVC, 21.3, and obstructive anatomy, 8.4. Of the 7 children who died, all were boys, 6 had complex TAPVC, 6 had obstruction, 2 had supracardiac TAPVC, 3 had mixed TAPVC, and 6 received postoperative extracorporeal membrane oxygenation. The child with simple TAPVC who died had associated bilateral pulmonary artery stenosis and disseminated intravascular coagulation. Of the patients with complex TAPVC, 4 died with multiple organ dysfunction, 1 with septic shock, and 1 with pulmonary hypertension. Six died in the hospital at 8 to 144 days post-operatively; the single late out-of-hospital death occurred at 63 postoperative days.

Table E2 shows the descriptive variables for the 34 surviving children, 31 with simple TAPVC and 3 with complex. The mean \pm SD levels of plasma lactate for all surviving children for the time periods were as follows: preoperatively, $2.5 \pm 2.0 \mathrm{mmol} / \mathrm{L}$ (range 0.8-8.4 $\mathrm{mmol} / \mathrm{L}$ ); first 24 hours postoperatively, $6.2 \pm 3.3 \mathrm{mmol} / \mathrm{L}$ (range 1.8-14.2 mmol/L); days 2 through 5 postoperatively, $3.5 \pm$ $3.1 \mathrm{mmol} / \mathrm{L}$ (range 1.0-12.6 mmol/L); and day 6 and later postoperatively, $1.3 \pm 0.45 \mathrm{mmol} / \mathrm{L}$ (range $0.1-2.5 \mathrm{mmol} / \mathrm{L}$ ). The highest plasma lactate level for each child occurred within 24 hours after surgery, except for 1 child with a level of $8.4 \mathrm{mmol} / \mathrm{L}$ before surgery, normal levels postoperatively, and a normal outcome. There were 7 of 34 children $(21 \%)$ with plasma lactate levels on day 1 elevated by at least $1 \mathrm{SD}$ for that period $(>9.5 \mathrm{mmol} / \mathrm{L})$. After Bonferroni correction, no differences were seen for demographic, preoperative, operative, or postoperative variables. Children with a racial background described by National Institutes of Health classification ${ }^{16}$ as of North American native peoples made up 13 (38\%) of the 34 assessed. Of these 13 children, infracardiac anatomy occurred in $8(61.5 \%)$ and obstruction in $5(38.5 \%)$. There were no statistically significant differences, however, in anatomic, operative, or perioperative variables between North American native and white children.

Growth and health outcomes for 34 survivors are described in Table 2. No child had ongoing hypoxia or known episodes of desaturation. The majority of hospitalizations and doctor visits were for pulmonary illnesses. Race, socioeconomic status, mother's schooling, and location of family home did not affect growth and health outcomes (data not shown).

There were no cases of cerebral palsy, visual impairment, or sensorineural hearing loss among the 34 survivors. No survivors were considered medically fragile, defined as 
TABLE 2. Growth and general health outcomes at 18 to 24 months of 34 survivors in relation to anatomic complexity of heart defect after total anomalous pulmonary venous connection repair

\begin{tabular}{lccc}
\hline Variable & $\begin{array}{c}\text { Total } \\
(\mathbf{n}=34)\end{array}$ & $\begin{array}{c}\text { Simple } \\
(\mathbf{n}=\mathbf{3 1})\end{array}$ & $\begin{array}{c}\text { Complex } \\
(\mathbf{n}=\mathbf{3})\end{array}$ \\
\hline $\begin{array}{l}\text { Length }<3 \text { rd percentile } \\
\text { Weight }<3 \text { rd percentile }\end{array}$ & $0(0 \%)$ & $0(0 \%)$ & $0(0 \%)$ \\
Microcephaly & $1(3 \%)$ & $1(3 \%)$ & $0(0 \%)$ \\
Gastrostomy feeds & $0(0 \%)$ & $0(0 \%)$ & $0(0 \%)$ \\
Hospitalization after initial & $2(6 \%)$ & $2(7 \%)$ & $0(0 \%)$ \\
$\quad$ discharge & $18(53 \%)$ & $18(58 \%)$ & $0(0 \%)$ \\
Visited doctor (except checkup) & $29(85 \%)$ & $27(87 \%)$ & $2(67 \%)$ \\
Supplemental oxygen & $0(0 \%)$ & $0(0 \%)$ & $0(0 \%)$ \\
Chronic pulmonary medication & $6(18 \%)$ & $5(16 \%)$ & $1(33 \%)$ \\
Chronic cardiac medication & $3(9 \%)$ & $2(7 \%)$ & $1(33 \%)$ \\
Tracheostomy & $1(3 \%)$ & $1(3 \%)$ & $0(0 \%)$ \\
\hline
\end{tabular}

All values represent numbers and percentages of patients. Analyses not done because of low numbers within complex cardiac anomaly group.

requiring long-term hospitalization or in-home nursing care. One child with simple TAPVC had cat-eye syndrome; growth and developmental scores were not in the delayed range. No other child had a chromosomal abnormality or neurologic syndrome. Mean scores for the 34 survivors were as follows: MDI $87 \pm 16$ and PDI $89 \pm 13$. MDI scores did not differ in relation to TAPVC anatomic complexity (simple $87 \pm 16$ vs complex $84 \pm 9, t=0.362, P>$ .2). Although there were almost 14 points of difference on PDI scores between the 31 children with simple TAPVC and the 3 with complex TAPVC, the small number of children in the latter group resulted in no significant difference in the scores (simple $91 \pm 13.1$ vs complex $77 \pm 8$, $t=1.642, P=.110)$. Scores show a shift to the left relative to population norms of $100 \pm 15$. The distributions of neurodevelopmental scores for survivors of simple and complex TAPVC repair are seen in Figure 1.

Among the 34 survivors with TAPVC, 5 had delays (scores $<70$ ) according to the MDI, PDI, or both. In the simple TAPVC group, 4 of 31 infants (13\%) had MDI scores lower than 70, and $2(7 \%)$ had PDI scores lower than 70 . None of the 3 children in the complex TAPVC group had scores lower than 70. With all variables listed in Table E2, comparisons were made between children with scores of at least 70 and children with delays. The only significant differences $(P<.05)$ found were as follows: weight at surgery, not delayed $3.6 \pm 0.62$ versus delayed $2.9 \pm 0.37$; weight in kilograms, $t=2.372, P=.024$; and lowest flow on cardiopulmonary bypass for longer than 10 minutes, not delayed $127.9 \pm 27.6$ versus delayed $145 \pm 11.2$ $\mathrm{mL} /(\mathrm{kg} \cdot \mathrm{min}), t=-2.708, P=.019$. With Bonferroni correction, there were no longer any significance differences. Similarly, considering only the 31 patients with sim-

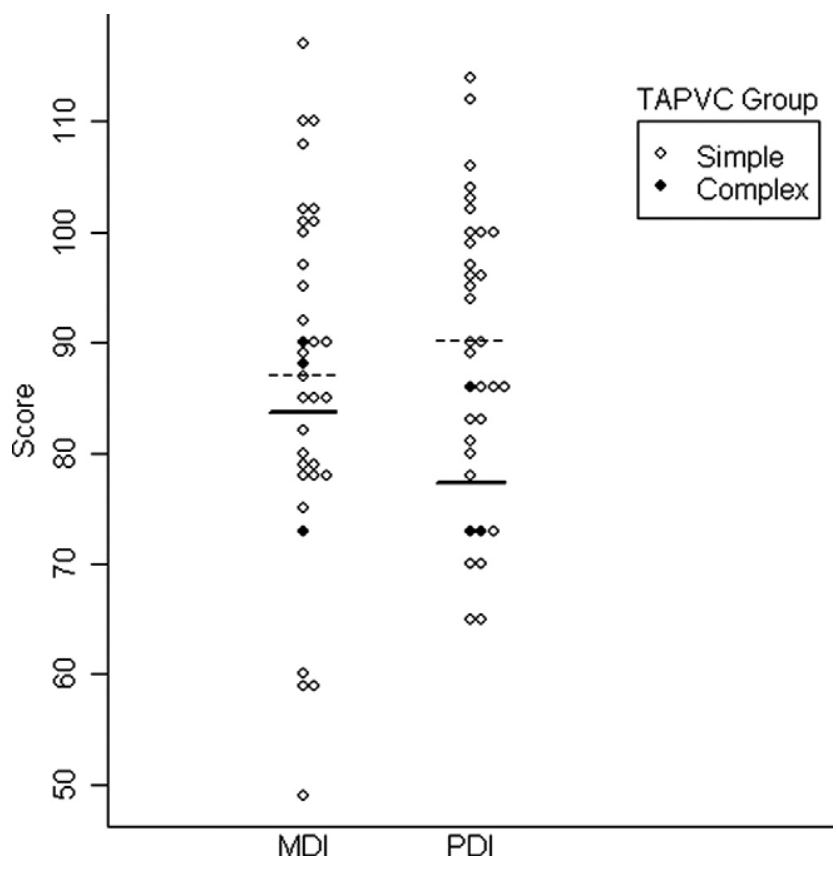

Figure 1. Distribution of individual 18- to 24-month mental and psychomotor developmental indices for 34 survivors (open circles for 31 simple and closed circles for 3 complex) after total anomalous pulmonary venous connection repair (TAPVC) at $\mathbf{6}$ weeks or younger, with broken line indicating mean scores after simple repair and solid line indicating mean scores after complex repair. MDI, Bayley Scales of Infant Development II (1993) Mental Developmental Index; PDI, Bayley Scales of Infant Development II (1993) Psychomotor Developmental Index.

ple TAPVC, there were no significant differences between children with scores above and below 70

All variables from Table $\mathrm{E} 2$ with a correlation $(P<.10)$ with MDI or PDI for all 34 survivors are shown in Table 3 , first for all 34 survivors and then for the 31 survivors with simple TAPVC. Stepwise multiple regressions were used to determine combinations of variables predictive of MDI and PDI for all 34 survivors. Only those variables of significance $(P<.05)$ from Table 3 were entered for each regression. The only variable to contribute to MDI was socioeconomic status, which explained $24.6 \%$ of the variability (slope 0.535 , SE $0.166, t=3.227, P=.003$ ). The only variables to contribute to the variability of PDI were weight at surgery, which explained $25.1 \%$ (slope 8.600 , SE 3.746, $t=2.296, P=.029)$, and highest plasma lactate on day 1 , which contributed another $10.4 \%$ to the variability of PDI, for a combined $35.5 \%$ explained variability (slope 1.432, SE $0.675, t=2.121, P=.043)$. Repeating the correlations of predictor variables with MDI and PDI for the 31 survivors after simple TAPVC resulted in the same variables showing significance $(P<.1$; Table 3$)$. The results of the stepwise 
TABLE 3. Two-tailed Pearson product-moment correlations $(r)$ with $\boldsymbol{P}$ values of less than .10 for predictor variables in relation to developmental indices for all 34 survivors after complete repair at 6 weeks or older for total anomalous pulmonary venous connection and for those 31 with simple anatomy

\begin{tabular}{|c|c|c|c|c|c|c|c|c|}
\hline \multirow[b]{3}{*}{ Predictor variables } & \multicolumn{4}{|c|}{ All assessed $(n=34)$} & \multicolumn{4}{|c|}{ Simple $(n=31)$} \\
\hline & \multicolumn{2}{|c|}{ MDI } & \multicolumn{2}{|c|}{ PDI } & \multicolumn{2}{|c|}{ MDI } & \multicolumn{2}{|c|}{ PDI } \\
\hline & $r$ & $P$ value & $r$ & $P$ value & $r$ & $P$ value & $r$ & $P$ value \\
\hline \multicolumn{9}{|l|}{ Demographic } \\
\hline Socioeconomic index & 0.496 & .003 & - & - & 0.518 & .003 & - & - \\
\hline Mother's schooling (y) & 0.397 & .020 & - & - & 0.392 & .029 & - & - \\
\hline Race & 0.340 & .049 & - & - & 0.372 & .040 & - & - \\
\hline Weight at surgery & - & - & 0.496 & .003 & - & - & 0.501 & .003 \\
\hline \multicolumn{9}{|l|}{ Preoperative } \\
\hline Highest oxygenation index & - & - & -0.347 & .054 & - & - & 0.332 & .068 \\
\hline Highest creatinine $(\mu \mathrm{mol} / \mathrm{L})$ & - & - & -0.315 & .070 & - & - & -0.340 & .061 \\
\hline \multicolumn{9}{|l|}{ Postoperative day 1} \\
\hline Highest plasma lactate $(\mathrm{mmol} / \mathrm{L})$ & - & - & -0.468 & .005 & - & - & 0.456 & .010 \\
\hline Highest creatinine $(\mu \mathrm{mol} / \mathrm{L})$ & - & - & -0.369 & .032 & - & - & -0.409 & .022 \\
\hline \multicolumn{9}{|l|}{ Postoperative days $2-5$} \\
\hline Highest dopamine used $(\mu \mathrm{g} /[\mathrm{kg} \cdot \min ])$ & - & - & -0.367 & .033 & - & - & 0.379 & .036 \\
\hline Lowest base deficit (mmol/L) & - & - & 0.299 & .097 & - & - & 0.362 & .054 \\
\hline \multicolumn{9}{|l|}{ Overall } \\
\hline Dialysis used & -0.374 & .055 & -0.332 & .091 & 0.374 & .055 & 0.332 & .091 \\
\hline
\end{tabular}

Variables that had no correlation $(P \leq .1)$ with either Mental or Psychomotor Developmental Index for all assessed or for the 31 simple cases are not given and include demographic variables of 2-parent family, English as first language, location, sex, cardiac and obstructive anatomy, complexity, 5-minute Apgar score, gestational age at birth, and age at surgery; operative variables of cardiopulmonary bypass time, lowest mean arterial pressure for more than 10 minutes on cardiopulmonary bypass, lowest flow on cardiopulmonary bypass for more than 10 minutes, lowest rectal temperature $\left({ }^{\circ} \mathrm{C}\right)$ during cardiopulmonary bypass for more than 10 minutes, lowest blood temperature immediately before deep hypothermic circulatory arrest, crossclamp time, deep hypothermic circulatory arrest time, and repeated cardiopulmonary bypass in operating room; variables at any time of lowest $\mathrm{PaO}_{2}$ and lowest arterial $\mathrm{pH}$; preoperative variables of lowest base deficit, highest dopamine used, lowest $\mathrm{PaO}_{2}$, lowest arterial $\mathrm{pH}$, highest plasma lactate, and duration of ventilation; postoperative, day 1 variables of highest dopamine used, lowest $\mathrm{PaO}_{2}$, lowest base deficit, lowest arterial pH, and highest oxygenation index; postoperative days 2 through 5 variables of lowest $\mathrm{PaO}_{2}$, lowest arterial $\mathrm{pH}$, highest lactate, highest creatinine, and highest oxygenation index; postoperative day 6 variables listed in Table 2; and overall variables of duration of hospitalization, duration of ventilation, time sternum was open, presence of convulsions, and need for cardiopulmonary resuscitation. MDI, Bayley Scales of Infant Development II Mental Developmental Index; PDI, Bayley Scales of Infant Development II Psychomotor Developmental Index; $C P B$, cardiopulmonary bypass.

multiple regressions were also similar. Socioeconomic status explained $24.3 \%$ of the variability of MDI (slope 0.654 ; SE $0.156 ; t=4.196 ; P<.001)$. For PDI, weight at surgery explained $22.6 \%$ of the variability; highest plasma lactate on day 1 contributed another $8.5 \%$, for a total of $31.1 \%$ of the variability explained (slope 1.416 ; SE $0.645 ; t=2.196$; $P=.036)$.

Because of the large proportion of the variability in MDI explained by socioeconomic status, correlations between this predictor variable and other demographic variables were completed for 34 children. Significant univariate correlations of socioeconomic status were mother's schooling $(r=0.776, P<.001)$ and race $(r=0.616, P<.001)$.

\section{Discussion}

This is the first report of early childhood outcomes of standardized neurodevelopmental assessment for survivors after early infant TAPVC repair. This indication in early childhood of the need for early developmental and edu- cational intervention supports previous recommendations that early intervention would benefit some children with TAPVC repair. ${ }^{10}$ Kirshbom and colleagues ${ }^{9}$ initially reported that most school-aged survivors of simple TAPVC can expect good functional outcomes, with $69 \%$ having average to above average school performance according to parent questionnaires. The need for educational support of TAPVC survivors was shown in a later study that used age-appropriate standardized tests; Kirshbom and associates ${ }^{10}$ reported that $58 \%$ of the 6 - to 19 year- old- children had delays in one or more domains tested: performance intelligence, mathematics achievement, attention, fine motor function, and visual motor integration. Through the early identification of children at risk for these school-related difficulties and the provision of educational intervention as indicated, we hope to be able to reduce adverse outcomes. ${ }^{10,12}$

Direct comparisons between a developmental test for 18to 24-month-old children, as we have done, and formal intellectual testing for school-aged children, as reported by 
Kirshbom and associates, ${ }^{10}$ cannot be completed because of the different ages of the children and the low socioeconomic status found in our population. For those surviving after repair of simple TAPVC, Kirshbom found the verbal IQ at a median of 11 years for 30 children to be $98.6 \pm 20.2$, not differing from population norms. For the comparable anatomic lesion, the MDI mean score for our 31 children after repair of simple TAPVC was $87 \pm 16$. Mean motor score for our 31 survivors of simple TAPVC, $91 \pm 13$, was below population norms. Although we cannot compare our data directly with those of Kirshbom and associates ${ }^{10}$ the performance IQ of children in that study was also below population normative data.

The lack of prediction of low mental scores in our study beyond unmodifiable variables related to socioeconomic status suggests that further exploration of other variables might be of benefit. Modifiable predictive variables of mental scores after TAPVC may yet be identified and should be a priority for future research. Our study identifies the potentially modifiable predictor of PDI to be higher plasma lactate within the first 24 hours after surgery. We have previously shown that postoperative plasma lactate may help to differentiate developmental outcomes. ${ }^{19}$ Delayed motor scores occurred in the simple and complex TAPVC groups, supporting the literature that documents lower fine motor and performance scores in this population. ${ }^{10}$ We have had similar findings in survivors after surgery for transposition of the great arteries. ${ }^{14}$ The particularly low mean motor score in our 3 children with complex anatomy, $77 \pm 8$, is similar to our findings in a previous study of 16 children after surgery for hypoplastic left heart syndrome $(68 \pm 19){ }^{13}$

The important role of socioeconomic status in the outcomes of infants with congenital heart surgery has been documented previously. ${ }^{20-23} \mathrm{We}$ sought factors that contributed to the lower socioeconomic status in this study: maternal education level and race were associated; however, we have not identified all contributing variables. The significant predictive value of socioeconomic status for the MDI in this study is in contrast to our previous publication on development after arterial switch operation, in which socioeconomic status and mother's education did not predict outcome ${ }^{14}$ Although it is common in the literature for socioeconomic status to relate to the developmental outcome of young children, it is unusual for it to be the only predictor. The usual method of addressing the effect of wide variations of socioeconomic status affecting outcome is to control for this variable. ${ }^{24,25}$ Such control was not possible in this outcome study. A combination of postsurgical TAPVC and low socioeconomic status strongly predicted neurodevelopmental delay. We recommend early intervention and education for all children with delays. Early individual assessment helps to identify children in need of additional neurodevelopmental or educational help.
We used The Bayley Scales of Infant Development II ${ }^{18}$ to assess the developmental level of these survivors at 18 to 24 months because this commonly used tool provides benefit to the children by outlining developmental strengths and weaknesses, thus assisting in planning individual developmental intervention as required. With this test, correlations with later outcome are best for the oldest children within the range of the test, which is up to 42 months of age. It is important to point out that The Bayley Scales of Infant Development II ${ }^{18}$ is not an intelligence test. Severe delay of more than 3 SD below mean on mental developmental tests is associated with a persistent mental delay. ${ }^{26}$ After neonatal cardiac surgery, there have been few long-term studies done comparing developmental testing with intelligence testing at school age, but one study after repair of transposition of the great arteries suggested 1-year developmental testing had only modest correlation with later performance. We plan to assess these children at 5 years. Thus far, only 13 have been assessed. The Pearson product correlation (2-sided) of the MDI with full-scale intelligence is 0.663 . Further testing is needed, however, to determine the utility of developmental tests in young children after neonatal intracardiac repair.

Fifty-eight percent of our 34 children with TAPVC repair required rehospitalization, whereas $9 \%$ of 82 children after the arterial switch operation, ${ }^{14}$ from this site and under the same system of medical care, required rehospitalization. In this study, these hospitalizations were largely for pulmonary illnesses regardless of demographic background, suggesting that children after TAPVC repair require close medical follow-up for pulmonary complications. These patients' general health was good, as supported by other studies. ${ }^{8-10}$ There was no microcephaly reported in our study, in contrast to $28 \%$ reported by Kirshbom and associates ${ }^{10}$ and $30 \%$ in a population of young children of similar age after complex heart surgery of several types. ${ }^{27}$ One child with simple TAPVC and a weight less than the 3 rd percentile had a gastrostomy tube.

Our study of consecutive admissions to our regional heart center with TAPVC shows a high incidence of children of native peoples (14 of 41 children, 34\%). This proportion of native children is 3.6 times higher than that among our population of children 6 weeks or younger with all types of severe complex cardiac anomalies cared for in 1996 through 1999 and previously published. ${ }^{13}$ This finding of a higher than expected incidence of TAPVC among native Canadians has been previously described. ${ }^{28} \mathrm{We}$ were unable to show that native children had more complicated operative or perioperative periods.

One of the major strengths of this study is its $100 \%$ follow-up of all survivors and accountability for all 41 children that underwent surgery. The major limitation to our study is the small number of survivors with complex TAPVC. This precluded the ability to test modifiable vari- 
ables in that group. In addition, the significantly large number of subjects with low socioeconomic status may have acted to limit the determination of predictive variables.

\section{Conclusions}

An increased survival of children with TAPVC during recent decades suggests a need to enhance our understanding of their neurodevelopmental outcomes. We strongly recommend that children who have been treated for this lifethreatening condition undergo early developmental assessments that may assist in planning early intervention programs to enhance their future skills. In this study, after evaluation of a wide variety of predictor variables, we found few modifiable predictors, suggesting that alternative predictors should be sought. The observation of a high prevalence of TAPVC among North American native peoples warrants further epidemiologic study.

We thank the families of these children for their active participation in the developmental sites across Western Canada and for their commitment to this project. We sincerely thank the research coordinators who made this research study possible: H. Christianson and D. Anseeuw-Deeks, Calgary, Alberta, V. Debooy, Winnipeg, Manitoba, T. Martindale, Saskatoon, Saskatchewan, and L. Sanders, Edmonton, Alberta.

\section{References}

1. Rowe RD. Anomalies of venous return. In: Keith JD, Rowe RD, Vlad PK, editors. Heart disease in infancy and childhood. 3rd ed. New York: Macmillan; 1978. p. 554

2. Raisher BD, Grant JW, Martin TC, Strauss AW, Spray TL. Complete repair of total anomalous pulmonary venous connection in infancy. J Thorac Cardiovasc Surg. 1992;104:443-8.

3. Sinzobahamvya N, Arenz C, Brecher AM, Blaschczok HC, Urban AE. Early and long-term results for correction of total anomalous pulmonary venous drainage (TAPVD) in neonates and infants. Eur J Cardiothorac Surg. 1996;10:433-8.

4. Rordam S, Abdelnoor M, Sorland S, Tjonneland S. Factors influencing survival in total anomalous pulmonary venous drainage. Scand J Thorac Cardiovasc Surg. 1994;28:55-60.

5. Sano S, Brawn WJ, Mee RB. Total anomalous pulmonary venous drainage. J Thorac Cardiovasc Surg. 1989;97:886-92.

6. Lupinetti FM, Kulik TJ, Beekman RH 3rd, Crowley DC, Bove EL. Correction of total anomalous pulmonary venous connection in infancy. J Thorac Cardiovasc Surg. 1993;106:880-5.

7. Caldarone CA, Najm HK, Kadletz M, Smallhorn JF, Freedom RM, Williams WG, et al. Surgical management of total anomalous pulmonary venous drainage: impact of coexisting cardiac anomalies. Ann Thorac Surg. 1998;66:1521-6.

8. Boger AJ, Baak R, Lee PC, Boersma E, Meijboom FJ, Witsenburg M. Early results and long-term follow-up after corrective surgery for total anomalous pulmonary venous return. Eur J Cardiothorac Surg. 1999; 16:296-9.

9. Kirshbom PM, Myung RJ, Gaynor JW, Ittenbach RF, Paridon SM, DeCampli WM, et al. Preoperative pulmonary venous obstruction affects long-term outcome for survivors of total anomalous pulmonary venous connection repair. Ann Thorac Surg. 2002;74:1616-20.
10. Kirshbom PM, Flynn TB, Clancy RR, Ittenbach RF, Hartman DM, Paridon SM, et al. Late neurodevelopmental outcome after repair of total anomalous pulmonary venous connection. $J$ Thorac Cardiovasc Surg. 2005;129:1091-7.

11. Wernovsky G, Shillingford AJ, Gaynor JW. Central nervous system outcomes in children with complex congenital heart disease. Curr Opin Cardiol. 2005;20:94-9.

12. Majnemer A, Limperopoulos C, Shevell M, Rosenblatt B, Rohlicek C, Tchervenkov C. Long-term neuromotor outcome at school entry of infants with congenital heart defects requiring open-heart surgery. J Pediatr. 2006;148:72-7.

13. Robertson CM, Joffe AR, Sauve RS, Rebeyka IM, Phillipos EZ, Dyck $\mathrm{JD}$, et al. Outcomes from an interprovincial program of newborn open heart surgery. J Pediatr. 2004;144:86-92.

14. Freed DH, Robertson CM, Sauve RS, Joffe AR, Rebeyka IM, Ross $\mathrm{DB}$, et al. Intermediate-term outcomes of the arterial switch operation for transposition of great arteries in neonates: alive but well? J Thorac Cardiovasc Surg. 2006;132:845-52.

15. Blishen BR. The 1981 socioeconomic index for occupations in Canada. Can Rev Sociol Anthropol. 1987;24:465-88.

16. NIH policy on reporting race and ethnicity data: subjects in clinical research [cited 2006 Aug 17]. Available from: URL: http:// grants2.nih.gov/grants/guide/notice-files/not-od-01-053.html.

17. Bax MC. Terminology and classifications of cerebral palsy. Dev Med Child Neurol. 1964;6:259-97.

18. Bayley N. Bayley scales of infant development manual. 2nd ed. San Antonio: Psychological Corp; 1993.

19. Cheung PY, Chui N, Joffe AR, Rebeyka IM, Robertson CM; Western Canadian Complex Pediatric Therapies Project, Follow-up Group. Postoperative lactate concentrations predict the outcome of infants aged 6 weeks or less after intracardiac surgery: a cohort follow-up to 18 months. J Thorac Cardiovasc Surg. 2006;130:837-43.

20. Forbess JM, Visconti KJ, Hancock-Friesen C, Howe RC, Bellinger DC, Jonas RA. Neurodevelopmental outcome after congenital heart surgery: results from an institutional registry. Circulation. 2002; 106(12 Suppl 1):I95-102.

21. Grabitz RG, Joffres MR, Collins-Nakai RL. Congenital heart disease: incidence in the first year of life. The Alberta Heritage Pediatric Cardiology Program. Am J Epidemiol. 1988;128:381-8.

22. Wernovsky G, Stiles KM, Gauvreau K, Gentles TL, duPlessis AJ, Bellinger DC, et al. Cognitive development after the Fontan operation. Circulation. 2000;102:883-9.

23. Goldberg CS, Schwartz EM, Brunberg JA, Mosca RS, Bove EL, Schork MA, et al. Neurodevelopmental outcome of patients after the Fontan operation: A comparison between children with hypoplastic left heart syndrome and other functional single ventricle lesions. J Pediatr. 2000;137:646-52.

24. Ricci M, Elliott M, Cohen GA, Catalan G, Stark J, de Leval MR, et al. Management of pulmonary venous obstruction after correction of TAPVC: risk factors for adverse outcome. Eur J Cardiothorac Surg. 2003;24:28-36.

25. Forbess JM, Visconti KJ, Bellinger DC, Howe RJ, Jonas RA. Neurodevelopmental outcomes after biventricular repair of congenital heart defects. J Thorac Cardiovasc Surg. 2002;123:631-9.

26. Honzik MP. Value and limitations of infant tests: an overview. In: Lewis M, editor. Origins of intelligence: infancy and early childhood. New York: Plenum Press; 1976. p. 46-67.

27. Limperopoulos C, Majnemer A, Shevell MI, Rohlicek C, Rosenblatt B, Tchervenkov C, et al. Predictors of developmental disabilities after open heart surgery in young children with congenital heart defects. J Pediatr. 2002;141:51-8.

28. McCrindle BW, Wood MM, Collins GF, Wheatley B, Rowe RD. An increased incidence of total anomalous pulmonary drainage among aboriginal Canadians. Can J Cardiol. 1996;12:81-5. 
TABLE E1. Anatomic diagnoses of the 9 infants with complex total anomalous pulmonary venous connection

\begin{tabular}{|c|c|c|c|c|c|c|c|c|}
\hline Case & $\begin{array}{l}\text { Pulmonary vein stenosis } \\
\text { or atresia }\end{array}$ & $\begin{array}{l}\text { Double-outlet } \\
\text { right ventricle }\end{array}$ & $\begin{array}{l}\text { VSD, multiple } \\
\text { VSDs }\end{array}$ & $\begin{array}{l}\text { Mitral valve } \\
\text { obstruction }\end{array}$ & $\begin{array}{l}\text { Atrioventricular } \\
\text { canal }\end{array}$ & $\begin{array}{c}\text { Aortic } \\
\text { stenosis }\end{array}$ & $\begin{array}{c}\text { Pulmonary arterial } \\
\text { stenosis }\end{array}$ & Dextrocardia \\
\hline 1 & Yes & & & & & & & Yes \\
\hline 2 & Yes & Yes & & & & & & \\
\hline 3 & Yes & & & & & & & \\
\hline 4 & Yes & & & & & & Yes & \\
\hline 5 & & Yes & & Yes & & & & \\
\hline $6 *+$ & & Yes & Yes & & Yes & & & \\
\hline $7^{*}$ & & & Yes & Yes & & & & \\
\hline $8^{*}$ & & & Yes & & & Yes & & \\
\hline 9 & & & Yes & & & & & \\
\hline
\end{tabular}

VSD, Ventricular septal defect. *Surviving at 2 years. †Reintervention for bidirectional cavopulmonary anastomoses at 13 months. 
TABLE E2. Demographic, operative, and perioperative descriptors for surviving 34 infants after surgery at 6 weeks or younger for total anomalous pulmonary venous connection mean (SD), $\mathbf{n}(\%)$

\begin{tabular}{|c|c|c|c|c|c|}
\hline & $\begin{array}{c}\text { Total } \\
(n=34)\end{array}$ & $\begin{array}{l}\text { Simple } \\
(\mathbf{n}=\mathbf{3 1})\end{array}$ & $\begin{array}{l}\text { Complex } \\
(\mathrm{n}=3)\end{array}$ & $\begin{array}{c}\text { Statistical } \\
\text { test* }^{*}\end{array}$ & $\begin{array}{c}P \\
\text { value }\end{array}$ \\
\hline \multicolumn{6}{|l|}{ Demographic } \\
\hline Socioeconomic indext (mean \pm SD) & $38.6 \pm 14.6$ & $37.6 \pm 14.7$ & $48.7 \pm 9.1$ & -1.272 & .213 \\
\hline Mother's schooling (y, mean \pm SD) & $12.3 \pm 3.1$ & $12.3 \pm 3.2$ & $12.7 \pm 2.1$ & -0.214 & .852 \\
\hline Two-parent family & $26(77 \%)$ & $23(74 \%)$ & $3(100 \%)$ & - & .603 \\
\hline English as first language & $30(88 \%)$ & $28(90 \%)$ & $2(67 \%)$ & - & .322 \\
\hline Race & & & & - & .27 \\
\hline White & $20(59 \%)$ & $18(58 \%)$ & $2(67 \%)$ & & \\
\hline Asian & $1(3 \%)$ & $0(0 \%)$ & $1(33 \%)$ & & \\
\hline North American native & $13(38 \%)$ & $13(42 \%)$ & $0(0 \%)$ & & \\
\hline Location & & & & 2.606 & .919 \\
\hline Large city $(>100,000)$ & $15(44 \%)$ & $13(42 \%)$ & $2(67 \%)$ & & \\
\hline Town $(1000-30,000)$ & $13(38 \%)$ & $12(39 \%)$ & $1(33 \%)$ & & \\
\hline Farm or village $(<1000)$ & $6(18 \%)$ & $6(19 \%)$ & $0(0 \%)$ & & \\
\hline Male sex & $21(62 \%)$ & $19(61 \%)$ & $2(67 \%)$ & - & 1 \\
\hline Apgar score at 5 min (mean \pm SD) & $8.3 \pm 0.97$ & $8.2 \pm 0.95$ & $9.3 \pm 0.58$ & -2.033 & .05 \\
\hline Birth gestation (wk, mean $\pm S D$ ) & $39.2 \pm 1.7$ & $39 \pm 2$ & $40 \pm 2$ & 0.491 & .627 \\
\hline \multicolumn{6}{|l|}{ Preoperative } \\
\hline Age at surgery $(\mathrm{d}$, mean $\pm \mathrm{SD})$ & $15 \pm 15$ & $15 \pm 14$ & $15 \pm 19$ & -0.006 & .995 \\
\hline Body weight at surgery $(\mathrm{g}$, mean $\pm \mathrm{SD})$ & $3.5 \pm 6.1$ & $3.5 \pm 0.64$ & $3.4 \pm 0.26$ & 0.426 & .673 \\
\hline Supracardiac anatomy & $15(44 \%)$ & $14(45 \%)$ & $1(33 \%)$ & - & $>.999$ \\
\hline Obstructive anatomy & $11(32 \%)$ & $10(32 \%)$ & $1(33 \%)$ & - & $>.999$ \\
\hline Highest dopamine used $(\mu \mathrm{g} /[\mathrm{kg} \cdot \min ]$, mean $\pm \mathrm{SD})$ & $2.7 \pm 5.6$ & $2.7 \pm 5.7$ & $3.3 \pm 5.8$ & -0.196 & .846 \\
\hline Epinephrine used & $4(12 \%)$ & $4(13 \%)$ & $0(0 \%)$ & - & $>.999$ \\
\hline Lowest $\mathrm{PaO}_{2}(\mathrm{~mm} \mathrm{Hg}$, mean $\pm \mathrm{SD})$ & $41.2 \pm 15.2$ & $41.6 \pm 15.8$ & $37.0 \pm 5.3$ & 0.493 & .625 \\
\hline Lowest base deficit (mmol/L, mean $\pm \mathrm{SD}$ ) & $-2.8 \pm 4.2$ & $-2.6 \pm 4.4$ & $-4.7 \pm 0.6$ & 0.796 & .433 \\
\hline Lowest arterial pH (mean \pm SD) & $7.33 \pm 0.09$ & $7.33 \pm 0.1$ & $7.34 \pm 0.05$ & -0.100 & .921 \\
\hline Highest plasma lactate $(\mathrm{mmol} / \mathrm{L}$, mean $\pm \mathrm{SD}$ ) & $2.5 \pm 2.0$ & $2.6 \pm 2.1$ & $1.8 \pm 0.8$ & 0.624 & .537 \\
\hline Highest serum creatinine $(\mu \mathrm{mol} / \mathrm{L}$, mean $\pm \mathrm{SD})$ & $61.4 \pm 2.7$ & $60.8 \pm 21.9$ & $68.3 \pm 34.1$ & -0.545 & .589 \\
\hline Highest oxygenation index (mean \pm SD) & $14.3 \pm 19.6$ & $15.0 \pm 20$ & $7 \pm 1.7$ & 0.667 & .510 \\
\hline Duration of ventilation $(d$, mean $\pm S D)$ & $2.1 \pm 3.3$ & $1.5 \pm 1.7$ & $8.3 \pm 8.5$ & -1.399 & .296 \\
\hline \multicolumn{6}{|l|}{ Operative } \\
\hline CPB time (min, mean $\pm \mathrm{SD}$ ) & $63.8 \pm 21.5$ & $59.4 \pm 13.9$ & $109 \pm 37.3$ & -2.289 & .146 \\
\hline $\begin{array}{l}\text { Lowest mean arterial pressure on CPB for }>10 \text { min } \\
(\mathrm{mm} \mathrm{Hg} \text {, mean } \pm \mathrm{SD})\end{array}$ & $24.2 \pm 6.9$ & $24.6 \pm 6.6$ & $20.3 \pm 10.5$ & 1.007 & .322 \\
\hline Lowest flow on CPB for $>10 \min (\mathrm{mL} /[\mathrm{kg} \cdot \min ]$, mean $\pm \mathrm{SD})$ & $129.5 \pm 23.6$ & $132 \pm 21.8$ & $100 \pm 25$ & 2.432 & .021 \\
\hline Lowest rectal temperature for $>10$ min on $\mathrm{CPB}\left({ }^{\circ} \mathrm{C}\right.$, mean $\left.\pm \mathrm{SD}\right)$ & $24.2 \pm 3.2$ & $24.4 \pm 3.2$ & $22.3 \pm 2.6$ & 1.096 & .281 \\
\hline $\begin{array}{l}\text { Lowest blood temperature immediately before DHCA } \\
\qquad\left({ }^{\circ} \mathrm{C} \text {, mean } \pm \mathrm{SD}\right)\end{array}$ & $19.0 \pm 2.3$ & $19.1 \pm 2.4$ & $18.4 \pm 1.5$ & 0.510 & .614 \\
\hline Crossclamp time (min, mean \pm SD) & $34.5 \pm 15.7$ & $31.7 \pm 8.1$ & $63 \pm 41.7$ & -1.297 & .323 \\
\hline DHCA time (min, mean \pm SD) & $27 \pm 8.7$ & $27.1 \pm 7.9$ & $26 \pm 17.6$ & .107 & .924 \\
\hline Repeat CPB in operating room & $2(6 \%)$ & $2(6 \%)$ & $0(0 \%)$ & - & $>.999$ \\
\hline \multicolumn{6}{|l|}{ Postoperative day 1} \\
\hline Highest dopamine used $(\mu \mathrm{g} /[\mathrm{kg} \cdot \min ]$, mean $\pm \mathrm{SD})$ & $6.8 \pm 6.4$ & $6.7 \pm 6.6$ & $8.3 \pm 2.9$ & -0.424 & .674 \\
\hline Lowest $\mathrm{PaO}_{2}(\mathrm{~mm} \mathrm{Hg}$, mean $\pm \mathrm{SD})$ & $73.2 \pm 52.5$ & $74.6 \pm 54.6$ & $59.3 \pm 21.9$ & 0.474 & .639 \\
\hline Lowest base deficit (mmol/L, mean $\pm \mathrm{SD}$ ) & $-1.0 \pm 3.5$ & $-1.1 \pm 10.3$ & $-0.67 \pm 4.0$ & -0.184 & .855 \\
\hline Lowest arterial pH (mean \pm SD) & $7.37 \pm 0.07$ & $7.33 \pm 0.07$ & $7.29 \pm 0.1$ & 1.079 & .289 \\
\hline Highest plasma lactate $(\mathrm{mmol} / \mathrm{L}$, mean $\pm \mathrm{SD})$ & $6.2 \pm 3.3$ & $6.3 \pm 3.4$ & $5.2 \pm 1.6$ & 0.568 & .574 \\
\hline Highest serum creatinine $(\mu \mathrm{mol} / \mathrm{L}$, mean $\pm \mathrm{SD})$ & $64.4 \pm 18.3$ & $64.6 \pm 18.8$ & $63.0 \pm 13.1$ & 0.141 & .889 \\
\hline Highest oxygenation index (mean \pm SD) & $7.9 \pm 4.2$ & $7.9 \pm 4.2$ & $8.3 \pm 5.1$ & -0.180 & .859 \\
\hline \multicolumn{6}{|l|}{ Postoperative days $2-5$} \\
\hline Highest dopamine used $(\mu \mathrm{g} /[\mathrm{kg} \cdot \min ]$, mean $\pm \mathrm{SD})$ & $8.6 \pm 20.8$ & $8.6 \pm 21.8$ & $8.3 \pm 3.8$ & 0.023 & .982 \\
\hline Lowest $\mathrm{PaO}_{2}(\mathrm{~mm} \mathrm{Hg}$, mean $\pm \mathrm{SD})$ & $64.1 \pm 24.8$ & $64.5 \pm 25.5$ & $60 \pm 19$ & 0.297 & .768 \\
\hline Lowest base deficit (mmol/L, mean $\pm \mathrm{SD}$ ) & $-0.344 \pm 3.6$ & $-0.448 \pm 3.8$ & $0.667 \pm 1.5$ & -0.502 & .619 \\
\hline
\end{tabular}


TABLE E2. Continued

\begin{tabular}{|c|c|c|c|c|c|}
\hline & $\begin{array}{c}\text { Total } \\
(\mathrm{n}=34)\end{array}$ & $\begin{array}{c}\text { Simple } \\
(\mathrm{n}=31)\end{array}$ & $\begin{array}{c}\text { Complex } \\
(\mathrm{n}=3)\end{array}$ & $\begin{array}{c}\text { Statistical } \\
\text { test }^{*}\end{array}$ & $\begin{array}{c}P \\
\text { value }\end{array}$ \\
\hline Lowest arterial $\mathrm{pH}$ (mean $\pm \mathrm{SD}$ ) & $7.34 \pm 0.07$ & $7.35 \pm 0.07$ & $7.29 \pm 0.09$ & 1.394 & .173 \\
\hline Highest plasma lactate $(\mathrm{mmol} / \mathrm{L}$, mean $\pm \mathrm{SD})$ & $3.5 \pm 3.1$ & $3.6 \pm 3.1$ & $2.5 \pm 0.8$ & 0.605 & .549 \\
\hline Highest serum creatinine $(\mu \mathrm{mol} / \mathrm{L}$, mean $\pm \mathrm{SD})$ & $79 \pm 33.9$ & $78.7 \pm 35.2$ & $71.3 \pm 18.6$ & 0.404 & .689 \\
\hline Highest oxygenation index (mean \pm SD) & $4.8 \pm 2.5$ & $4.65 \pm 2.4$ & $6 \pm 2.6$ & -0.912 & .368 \\
\hline \multicolumn{6}{|l|}{ Postoperative day 6 and later } \\
\hline Highest dopamine used $(\mu \mathrm{g} /[\mathrm{kg} \cdot \min ]$, mean $\pm \mathrm{SD})$ & $1.5 \pm 3.4$ & $1.3 \pm 3.1$ & $3.3 \pm 5.8$ & -0.991 & .329 \\
\hline Epinephrine used & $6(18 \%)$ & $5(15 \%)$ & $1(33 \%)$ & - & .464 \\
\hline Lowest $\mathrm{PaO}_{2}(\mathrm{~mm} \mathrm{Hg}$, mean $\pm \mathrm{SD})$ & $66.8 \pm 16.4$ & $66.8 \pm 17.3$ & $56.3 \pm 11.7$ & 1.013 & .319 \\
\hline Lowest base deficit $(\mathrm{mmol} / \mathrm{L}$, mean $\pm \mathrm{SD}$ ) & $0.065 \pm 4.7$ & $-1.07 \pm 4.8$ & $1.7 \pm 3.2$ & -0.620 & .540 \\
\hline Lowest arterial pH (mean \pm SD) & $7.37 \pm 0.06$ & $7.37 \pm 0.06$ & $7.36 \pm 0.06$ & 0.078 & .938 \\
\hline Highest plasma lactate $(\mathrm{mmol} / \mathrm{L}$, mean $\pm \mathrm{SD})$ & $1.3 \pm 0.45$ & $1.3 \pm 0.46$ & $1.3 \pm 0.46$ & -0.038 & .970 \\
\hline Highest serum creatinine $(\mu \mathrm{mol} / \mathrm{L}$, mean $\pm S D)$ & $59.7 \pm 28.7$ & $61.6 \pm 27.9$ & $40.0 \pm 17.3$ & 1.30 & .203 \\
\hline Highest oxygenation index (mean \pm SD) & $2.7 \pm 2.1$ & $2.7 \pm 2.2$ & $2.7 \pm 1.5$ & 0.033 & .974 \\
\hline \multicolumn{6}{|l|}{ Overall } \\
\hline Duration of hospitalization $(d$, mean $\pm S D$ ) & $18.9 \pm 12.9$ & $18.3 \pm 13.1$ & $26.1 \pm 4.4$ & -0.987 & .331 \\
\hline Duration of ventilation (d, mean $\pm S D$ ) & $8.5 \pm 7.5$ & $8.3 \pm 7.8$ & $10.3 \pm 4.0$ & -0.444 & .660 \\
\hline Duration sternum open $(d$, mean $\pm S D)$ & $2.7(5.8)$ & $2.6(5.9)$ & $4(4.6)$ & -0.401 & .691 \\
\hline Convulsions at any time & $3(10 \%)$ & $3(10 \%)$ & $0(0 \%)$ & - & $>.999$ \\
\hline Cardiopulmonary resuscitation at any time & $2(6 \%)$ & $2(6 \%)$ & $0(0 \%)$ & - & $>.999$ \\
\hline Dialysis at any time & $1(3 \%)$ & $1(3 \%)$ & $0(0 \%)$ & - & $>.999$ \\
\hline
\end{tabular}

After Bonferroni correction, only differences of $<.0001$ remain significant. CPB, Cardiopulmonary bypass; DHCA, deep hypothermic circulatory arrest. *Statistical tests: $\chi^{2}, t$ test, 2-sided Fisher exact test. $†$ Blishen BR. The 1981 socioeconomic index for occupations in Canada. Can Rev Sociol Anthropol. 1987;24:465-88. 